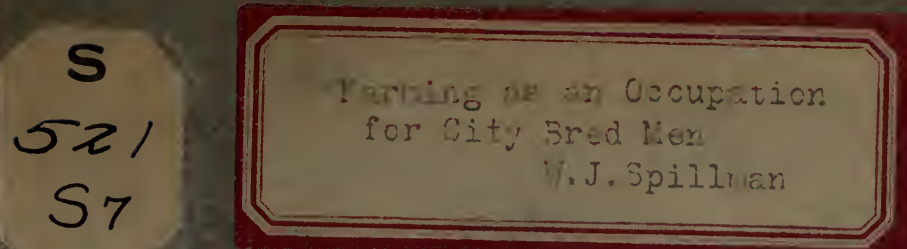

\title{
UC-NRLF
}

||||||||||||||||||||||||||||||||||||||||||||

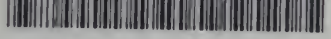

\$B $115 \quad 745$

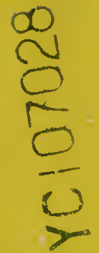




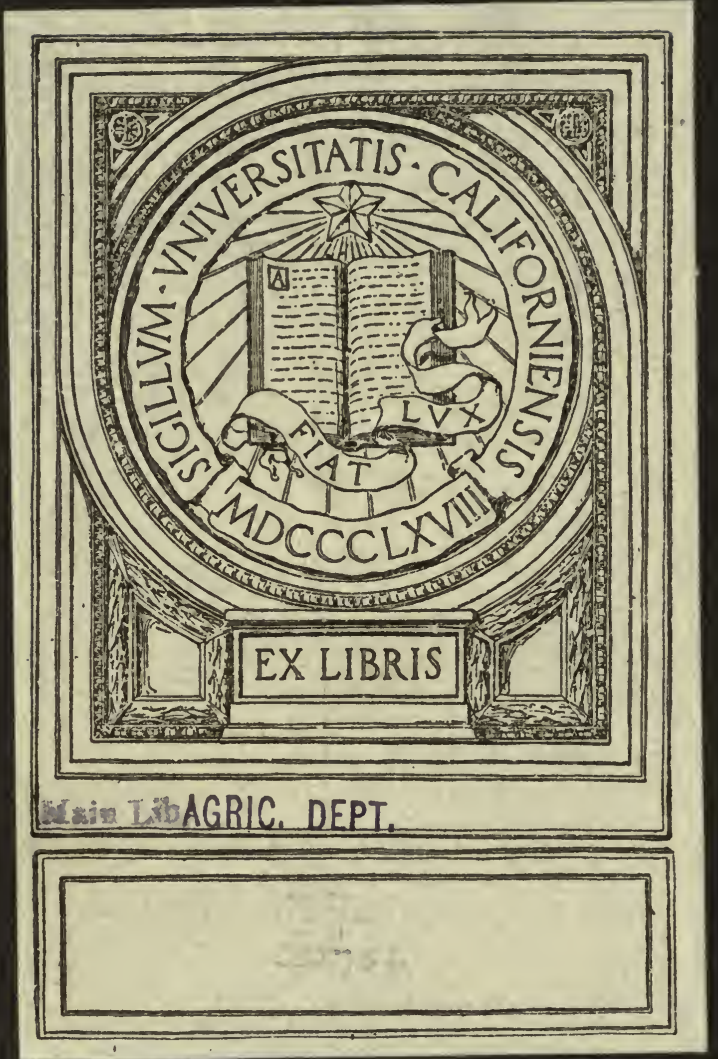




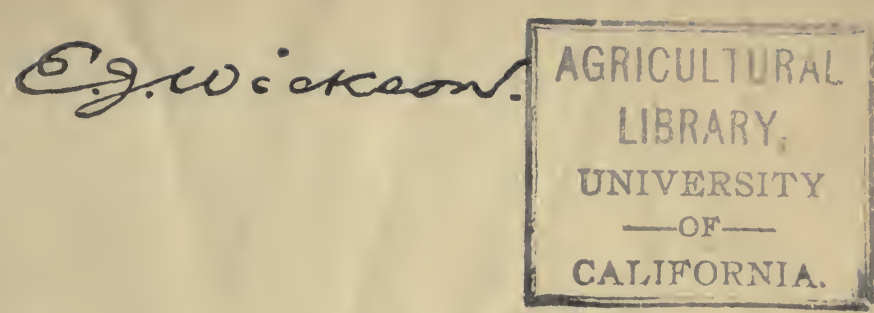

Y. B. Separate 509.

\section{FARMING AS AN OCCUPATION FOR CITY-BRED NEN.}

By

W. J. SPILLMAN,

Agriculturist in Charge of Office of Farm Management, Bureau of Plant Industry.

[ [From Yearbook of Department of Agriculture for 1909.] 


\section{CONTENTS.}

Success in mercantile, manufacturing, or transportation enterprises......... 239

Conditions affecting farmers. ....................................... 239

Limited opportunities of the farm laborer.......................... 240

Conditions the city man must meet in farming ....................... 240

As a gardener in the suburbs...................................... 241

Some instances of success ........................................... 241

Changed conditions in recent years............................... 242

Capital required...................................................... 242

Equipment .......................................................... 243

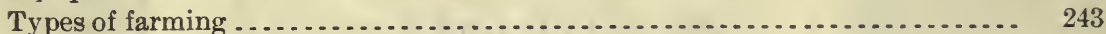

Sources of information............................................. 244

The agricultural experiment stations........................... 245

United States Department of Agriculture....................... 245

Farmers' institutes ........................................... 246

Movable schools of agriculture .............................. 246

Correspondence ............................................. 246

Agricultural high schools and colleges .......................... 247

Books on farming ............................................ 247

Departmental and private aid ................................. 247

Advantages of a farmer's life....................................... 247

11

Mitin $Y i$ i's,

Arric. Jept

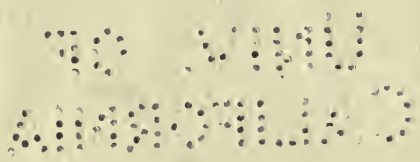




\title{
FARMING AS AN OCCUPATION FOR CITY-BRED MEN.
}

\author{
By W. J. Spillman, \\ Agriculturist in Charge of Office of Farm Management, \\ Bureau of Plant Industry.
}

SUCCESS IN MERCANTILE, MANUFACTURING, OR TRANSPORTATION ENTERPRISES.

A study of the history of those men who direct the affairs of large mercantile, manufacturing, and transportation enterprises usually reveals a steady progress from a beginning as a low-salaried employee step by step to positions of greater responsibility, and finally to the position of directing head of the enterprise. The men who thus gradually work themselves up from lower positions are endowed with the spirit of work. In nearly all industries of the classes mentioned the hours of work are so limited that even the most humble employee has some time which he can devote either to recreation or to study. The men who go to the top in business affairs are usually those who do not know what recreation means, but spend their spare time in intelligent preparation for greater usefulness to their employers. Many instances might be cited where men who are now directing large enterprises began at' a low salary in a position requiring hard work. The humblest employee in such lines of business has the opportunity, if he has the ability, to rise to a high position.

\section{CONDITIONS AFFECTING FARMERS.}

In farming it is different. There are practically only three grades in this business, namely, the farm laborer, the tenant, and the proprietor. While it is possible for the laborer to become a tenant, and then by careful study and great frugality ultimately to become an independent proprietor, or even to become a proprietor directly, in a small way, from his savings as a farm laborer, generally speaking there is not the opportunity in farming for the laborer to pass by gradual steps to a position of importance in the industry, because we do not ordinarily find series of positions, with graduated salaries, which form the stepping stones for the ambitious and able young man. In the first place, on the average farm there is little or no profit; that is, if we count out wages for the 
farmer and his family and interest on the investment, there is usually no balance, and on many farms the balance is on the wrong side of the ledger.

To state the reasons for this condition of affairs would lead us too far away from our present purpose. It will suffice here merely to state that ordinarily profits in farming are not large, and that therefore farm wages are not high. It takes several years of selfdenial and careful saving for the farm laborer to lay by enough to become a tenant or a small proprietor. Nevertheless, this has been done repeatedly and can be done if the laborer has sufficient intelligence and determination.

\section{LIMITED OPPORTUNITIES OF THE FARM LABORER.}

As a farm laborer a young man has some chance to study agricultural literature and to learn many necessary details of farming, without which knowledge it would be unwise to undertake farming as a means of livelihood. But the opportunity for study on the part of the farm laborer is not as great as it ought to be. Many farmers attempt to overcome low profits by long hours of labor instead of by intelligent study of the details of their business. Comparatively few farmers limit the hours of labor in such a way as to give time for a proper study of their business. Under ordinary circumstances, therefore, it is hardly practicable for the ordinary city employee to become a farmer through the position of farm laborer. In the first place, even the farm laborer must have a knowledge of details which it takes some years of experience to acquire, in order to make his services of value to the farmer. In the second place, the standard of living of the average farm laborer would greatly discourage the city-bred family. Yet where it is possible to secure employment with a view to learning the details of farming, it is wise to do so, provided the city man who is trying to.break away from the city and get on to the land has the courage to undergo the hardships incident to such a change-speaking, of course, of the man who has little or no capital with which to begin business for himself.

\section{CONDITIONS THE CITY MAN MUST MEET IN FARMING.}

It is still less feasible for the city man with no knowledge of farming to begin as a tenant farmer. The tenant must pay rent and must know how to farm in order to make ends meet. To move from the city to the country, with no capital, would appear, therefore, to be a very serious undertaking, and the writer would not advise city people to undertake it. However, if a small capital has been saved up the move can be made; but in practically all cases the beginning should be made not as a farm laborer or as a tenant, but as a small proprietor, the size of the establishment depending, of 
course, upon the capital available. It is a good plan for the city man who has the means to take some sort of course in a school of agriculture as a preparation for farming. Schools of this kind are multiplying rapidly in this country. Every State has its agricultural college, and many of the States are building agricultural schools of secondary grade. The latter are particularly valuable to the city man who would learn how to farm, as they give more attention to the practical details of farming than the colleges do, the function of the agricultural high school being primarily to turn out men fitted for farming, while the main function of the college is to turn out men fitted for agricultural investigation and teaching.

\section{AS A GARDENER IN THE SUBURBS.}

Whenever it is feasible a very good plan for the city man who has no knowledge of farming and who desires to become a farmer is to move to the suburbs and begin in a small way as a gardener. Ai first the principal aim should be to produce truck crops for home consumption. As experience is gained the industry may be enlarged and a market established. Many men have made the transition in this manner. Others have started with one or two cows, and have let the business grow from the profits obtained in it. Others have succeeded by beginning in a small way with poultry or fruit. The knowledge gained in this way, both as regards the details of farming and concerning methods of marketing, finally enables the beginner to abandon his city employment and become a farmer.

\section{SOME INSTANCES OF SUCCESS.}

A few men have succeeded without this gradual transition. They have moved boldly to the country, put their capital into land, and by hard work, much study, and exceedingly frugal living for a few years, until the business has been learned and a profit assured, have been highly successful. Farmers' Bulletins Nos. 242 and 355, issued by the United States Department of Agriculturè, give accounts of two farmers who have succeeded in this manner. Such changes are usually accompanied, for a few years, by the severest kind of hardship; but if the man is intelligent, a close observer, and not afraid of work, it is possible to succeed under such conditions.

An interesting case of this kind came to notice recently. At the Iowa State Corn Show in 1909 the ear of corn which took the grand championship prize, and which sold at auction for $\$ 160$, was produced by a farmer who ten years previously was a driver of a laundry wagon in the city of Des Moines. It must be recognized, however, that men who have thus succeeded have invariably been men of unusual ability. 


\section{CHANGED CONDITIONS IN RECENT YEARS.}

In some respects it is more difficult at the present time to break away from city employment and establish oneself on the land than it was a generation ago. At that time there was plenty of land to be homesteaded. Especially in the Middle West, where most of this land was available, the soil was rich and its fertility needed no attention. It did not take long for the beginner to learn how to grow crops successfully on this rich virgin soil and to make farming distinctly profitable. When good land was thus available for the taking, thousands of farm homes were successfully established by men having little previous knowledge of the business. At the present time there is practically no desirable land left for homesteads. The beginner must buy land usually at a considerable expense. Not only that, but in most parts of the country the land has been farmed so long without attention to fertility that it will no longer produce crops by the slipshod methods formerly in vogue. Experience and a knowledge of principles are therefore much more necessary at the present time than was the case a generation ago. In fact, many experienced farmers to-day are not making a good living for the simple reason that they do not possess the knowledge of the principles involved in their business, and unfortunately only too often the farmer is not aware of his lack of knowledge. The city man has the advantage that he realizes his ignorance and is willing to learn.

On the other hand, agricultural science has developed wonderfully in the last quarter of a century, and the literature of the subject is correspondingly more abundant and more reliable. Hence, the beginner may receive more help from others than was the case a generation ago. The sources of information on which the farmer may draw will be referred to more specifically later in this article.

\section{CAPITAL REQUIRED.}

No definite amount of capital can be stated as a sufficient sum on which to begin farming any more than it can be done in the mercantile business. A great deal depends on the price of land and the magnitude of the undertaking. Just as the merchant may begin with a modest stall and a few dollars' worth of goods, so the farmer may begin with 1 acre of land or less, on which he may raise part of the food for his family, eking out a living by working part of the year for someone else, or he might buy a large farm and equip it fully. It may be said, however, and with some assurance, that the man without farm experience and without a knowledge of the principles involved in farming who starts the business on an elaborate scale is foredoomed to failure unless he is so fortunate as to command the services of a trained manager. Furthermore, it is next to impossible 
to secure such services. Competent farmers are usually engaged in business for themselves, and our schools of agriculture have not yet fairly begun to supply the demand for men of this class. There is hope, however, that in the not distant future many young men without the capital to start into business for themselves will be trained for the management of agricultural properties, as a few are to-day. When the number of such men is sufficient to meet the demand we may expect an important development of large agricultural enterprises.

We shall not attempt here to deal with the case of the wealthy city man whose farm is to be simply a country home. Usually such farmers spend more in equipment than the farm can ever be made to pay for. It is our aim rather to deal with the case of the man with small or moderate means, who must make his living from the farm. The first and most important principle to get fixed in mind is that of avoiding unnecessary expenditures. The commonest mistake of the city man who undertakes farming is the purchase of equipment which is not necessary to his business. The natural impulse is for the beginner to purchase all he thinks he will need. It is decidedly the best policy, at least until one has become experienced and has a good knowledge of what equipment is necessary, to buy nothing not absolutely essential until the farm begins to pay. After that one may do as he likes with the profits of his farm.

\section{EQUIPIENT.}

The question of farm equipment has been little studied, the only deliberate study of such equipment known to the writer being that inaugurated by the Office of Farm Management a few years ago. It is a very complex and difficult subject. The character and amount of equipment are determined by many elements, such as climate, the character of the crops grown, the kind of live stock kept, the character and condition of the soil, and the extent of farming operations undertaken. Even if complete knowledge of farm equipment were available, it would be impossible in an article as brief as this to outline the subject in full, because it is too extensive. Yet, when the farmer has chosen his location and determined upon the type of farming he is to follow, the Office of Farm Management can give him a good deal of valuable information concerning the equipment he will need. We hope at some future time to have an ample list of publications on this subject.

\section{TYPES OF FARMING.}

Perhaps the most important point the beginner must decide is the type of farming to be followed. This question is discussed at length in an article in the Yearbook of the Department of Agriculture for 
1908 , pages 351 to 366 . It gives a general discussion of practically all the types of farming found in the United States, and suggestions are made about those types best suited to beginners. There is also some discussion of the amount of equipment required.

One important consideration, which is not brought out in the article referred to, is that, if in a community the farmers generally buy a commodity they can produce, the price of that commodity will be high and its production profitable. A conspicuous example is found in the tobacco and cotton growing regions, where the farmers usually buy their hay. This hay is produced in the North, and the high freight rate on so bulky a commodity causes it to be high priced. Occasionally one finds in those regions a farmer who devotes most of his energies to the production of hay. Such farmers usually make more money than their neighbors who buy hay. In fact, hay growing is a fairly simple type of farming that is usually profitable, and there are extensive regions in the United States where hay growing is the best type of farming for the beginner, provided he has capital enough to begin on a considerable scale. The principal difficulties met with in this type of farming are that considerable equipment is required and a considerable area of land is necessary from which to secure an adequate income for a farm family. The curing of hay, so as to be able to put on the market a good quality of this product, is also something which can not be learned entirely from books, but requires considerable experience for its successful conduct. On the other hand, the hay crop is fairly certain if the right crops are chosen, and if large yields are obtained the returns are good.

\section{SOURCES OF INFORMATION.}

Farming requires not only experience but a great deal of detailed knowledge of many things. For instance, one must be able to judge when the soil is in condition to be plowed or tilled. This is especially the case on heavy soils. If a clay soil is handled while it is wet and dry weather supervenes, the soil becomes baked into hard clods, which rain alone can pulverize. On the other hand, if it is plowed when it is too dry, a clay soil breaks up into large lumps, on which it is of little use to plant any kind of crop. But if the plowing be done when the soil is of a proper consistency, clay soils pulverize readily and the subsequent tillage operations are simple. On sandy soils one does not need to give so much attention to the condition of the soil for plowing or tilling, though even on this class of soils some experience in soil management is necessary in order to secure the best results.

The farmer must also understand how to maintain the fertility of the soil; hence he must have a knowledge of fertilizers, of manures, of the effect of lime, etc. He must also know the nature of many 
kinds of plants and understand their requirements. In practically all kinds of farming some live stock are necessary, and the farmer must know how much shelter these stock require, what kind of food they need, how much, etc. He must also know the time to plant and to harvest, and how to secure and manage labor, unless he is so fortunate as to be able to dispense with hired labor.

Part of this knowledge may be obtained from books, but a great deal of it can be obtained only by experience. This is especially true as regards knowledge of the soil. Even the agricultural scientist does not yet know all about the soil, and the best books on the subject leave much to be learned by experience.

In most communities the beginner can gain much information from his neighbors, especially about the time of planting and harvesting, when the soil is in condition for plowing and tilling, the amount of feed necessary for his live stock, etc. On the other hand, one's neighbors are often poor advisers, especially if the new farmer is attempting to do something which has not before been successfully done in the community. The average farmer is inclined to discourage innovations of all kinds and is ready to predict failure of new methods and of men new at the business.

Fortunately, agricultural papers are abundant, and many of them are very reliable in what they teach. Every farmer should take several of these. Some of the best farm papers relate to general farming, while almost every phase of farming is discussed by special journals. For instance, there are numerous journals devoted to poultry, and practically every kind of stock has one or more journals devoted to it. There are also good journals which give special attention to truck growing, fruit growing, and the like. It is a good plan for the farmer to take one or two of the best of the journals devoted to general farming in addition to a few of the special journals relating to the phases of farming which he is practicing.

THE AGRICULTURAL EXPERIMENT STATIONS.

In every State there is an agricultural experiment station which issues bulletins on various phases of farming. These bulletins are sent free to all applicants in the States where they are published. Some of the stations send bulletins to farmers in other States.

UNITED STATES DEPARTMENT OF AGRICUltURE.

In addition to bulletins from the experiment stations, the United States Department of Agriculture issues an extensive series of bulletins covering very many phases of farming. Most of these bulletins are sent free to all applicants. This is especially true of the series known as Farmers' Bulletins, of which there are now several hun- 
dred. There is probably no farmer in the country who will not find some of these Farmers' Bulletins highly valuable. Complete lists of all the publications of the Department of Agriculture may be obtained for the asking, and from these lists such publications as are desired may be selected.

\section{FARMERS' INSTITUTES.}

In practically every State farmers' institutes are conducted. These are meetings of farmers at which various agricultural questions are discussed. The speakers are usually practical farmers who have made a distinct success of their work, or trained agriculturists who have a wide knowledge of agricultural conditions in the State. The most experienced farmer finds these institutes of great value.

\section{MOVABLE SCHOOLS OF AGRICULTURE.}

In some sections of the United States traveling instructors are provided either by the State or by the United States Department of Agriculture. This is especially the case in the cotton-growing States and in dairy communities in the Northern States. Some of the States maintain traveling dairy schools, which go about from place to place giving a short course of practical demonstrations in the handling of milk, the manufacture of butter, the use of dairy apparatus and machinery, etc. These demonstrations are usually accompanied by lectures on the feeding and care of dairy cows and other kindred topics. In a good many of the corn-growing States in recent years special corn schools have been held during the winter season, when the farmers can best attend them. As the price of farm land rises and the original fertility of the soil is exhausted, schools of this character become more and more necessary. There will undoubtedly be an extensive development of instruction of this character in the near future.

\section{CORRESPONDENCE.}

In addition to the sources of information already outlined, farmers can usually secure much valuable information by correspondence with the state agricultural colleges and the United States Department of Agriculture. A number of the agricultural colleges maintain correspondence courses in agriculture. There are also some private schools which do the same. Nearly all of the agricultural colleges, at some time during the winter season, offer special short courses in practical agriculture. The expense of attending these short courses is nominal, and the information to be gained makes attendance well worth while. Such courses are of more help to the experienced farmer than they are to the beginner, for the reason that the information given can not be assimilated without some farm experience. 


\section{FARMING AS AN OCCUPATION FOR- CITY-BREP, NEN, $; 247$}

AGRICULTURAL HIGH SCHOOLS AND COLLEGES.

The agricultural high schools and colleges have already been mentioned. In recent years the attendance at these schools from the cities has shown a marked increase, and, where one has the means, it is an excellent plan to take a course at such an institution before attempting farming. While taking this course it is highly desirable that the student spend his vacations at farm work.

BOOKS ON FARMING.

The number of books published relating to various phases of farming is very extensive; so much so, in fact, that the farmer is at a loss to know what books to buy. He can secure much valuable advice on this point by corresponding with the agricultural colleges and the Department of Agriculture at Washington, D. C.

\section{DEPARTMENTAL AND PRIVATE AID.}

A few years ago there was established in the Bureau of Plant Industry of the United States Department of Agriculture an Office of Farm Management. In many cases the employees of this office are able to render valuable service to farmers by way of advice concerning types of farming to undertake, equipment to buy, crops to grow, the relative acreage of these crops, how to secure good seed, etc. Representatives of this office are found in most of the States.

More recently a number of men have established themselves as agricultural experts, who visit farms and give advice on many phases of farm management, charging fees for such services.

\section{ADVANTAGES OF A FARMER'S LIFE.}

While it has been necessary in this article to dwell more particularly on the difficulties confronting the family who would change from some other business to farming, the advantages of farming must not be overlooked. In the first place, the farmer, if he is at all successful, has no fear of being displaced. He commands his own time and leads an independent life. In the second place, if he is wise, he may himself produce nearly all the food necessary for his family. He may maintain a good garden, an orchard, a flock of poultry, keep a few cows and pigs, and grow most of his own bread. If the wife and daughters know how to prepare food in an appetizing manner and understand how to be frugal, the actual money expense for the farm living may be made very small, while at the same time the standard of living, from the standpoint of food, may be much higher than is possible even with wealthy people in the city.

The income from farming depends more upon the farmer himself than it does upon any other one factor. An intelligent man who 
248 YEARBOOK OF THE DEPARTMENT OF AGRICULTURE.

must depend upon his own labor may live well on the farm after he has acquired a satisfactory knowledge of the business. If he can command considerable capital he may profit by the labor of others, and if his capital is large enough and he is a good business manager he may live even luxuriously. But the beginner, even with considerable capital, must be prepared to bear some hardships while he is learning the business.

O 
Gaylord Bros. Makers

Syracuse, N. Y.

PAT. JAN. 21, 1908

\section{U.C. BERKELEY LIBRARIES

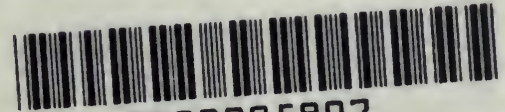 B003005907}

$$
272720
$$

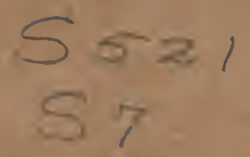


